\title{
Blends of cassava starch with banana flours as raw materials for gluten-free biscuits
}

\section{Misturas de amido de mandioca com farinhas de banana como matérias-primas para biscoitos sem glúten}

\author{
Magali Leonel ${ }^{1 *}$; Thaís Paes Rodrigues dos Santos ${ }^{2}$; Sarita Leonel ${ }^{3}$; Ciro Hugo \\ Elnatan de Souza Santos ${ }^{4}$; Giuseppina Pace Pereira Lima ${ }^{5}$
}

\section{Highlights}

Flours from peel and pulp of banana have high levels of functional components.

Banana peel flour has more pronounced effect on properties of biscuits.

Cassava starch is a good substitute for wheat in banana biscuits.

\begin{abstract}
The growth in demand for gluten-free products linked mainly to health aspects has led to an increased interest in the production of mixed flours for use in bakery products. This work aimed to evaluate the use of different mixtures of cassava starch with banana flour, obtained from the pulp and peel of green fruits, for the production of gluten-free biscuits. In the preparation of the biscuits, seven mixtures were prepared with varying percentages of cassava starch, banana pulp flour and banana peel flour. A formulation with wheat flour was used as a control. Wheat flour, cassava starch and banana flours were analyzed for chemical composition. The results showed that the banana peel flour stood out for its higher levels of proteins, fibres, lipids, ash, total phenols, total flavonoids and antioxidant activity which make this flour effective as a functional additive. However, the results of physical and sensory characteristics of the biscuits showed that the variation in the percentage of banana peel flour led to greater changes in the quality attributes of the biscuits, so the percentage of inclusion should be limited. Banana pulp flour (UBF) had high starch content, however, the biscuits produced with higher percentages of this flour and lower percentages of cassava starch showed lower propagation rates, greater hardness and less sensory acceptance, showing the importance of the starchy raw material in the physical properties of biscuits. Formulations containing cassava starch mixed with up to $15 \%$ banana flour (1:1, pulp and peel) are a good basis for making gluten-free biscuits.
\end{abstract}

Key words: Fruit flours. Starch. Celiac. Sensorial acceptance.

1 Full Prof., Universidade Estadual de São Paulo, UNESP, Center for Tropical Roots and Starches, Botucatu, SP, Brazil. E-mail: magali.leonel@unesp.br

2 Postdoctoral Fellow, UNESP, College of Agricultural Sciences, Botucatu, SP, Brazil. E-mail: thaispaes.btu@gmail.com

${ }^{3}$ Full Prof., UNESP, College of Agricultural Sciences, Botucatu, SP, Brazil. E-mail: sarita.leonel@unesp.br

${ }^{4}$ Undergraduated in Nutrition, UNESP, Institute of Biosciences, Botucatu, SP, Brazil. E-mail: cirohug@gmail.com

5 Full Prof., UNESP, Institute of Biosciences, Botucatu, SP, Brazil. E-mail: pace.lima@unesp.br

* Author for correspondence

Received: Oct. 20, 2020 - Approved: Jan. 21, 2021 


\section{Resumo}

O crescimento da demanda por produtos sem glúten, ligado principalmente à aspectos de saúde, tem levado a um aumento do interesse na produção de farinhas mistas para uso em produtos de panificação. Este trabalho teve como objetivo avaliar a utilização de diferentes misturas de fécula de mandioca com farinhas de banana, obtidas a partir da polpa e da casca de frutos verdes, para a produção de biscoitos sem glúten. No preparo dos biscoitos foram feitas sete misturas com percentuais variáveis de fécula de mandioca, farinha de polpa de banana e farinha de casca de banana. Uma formulação com farinha de trigo foi usada como padrão. A farinha de trigo, a fécula de mandioca e as farinhas de banana foram analisadas quanto à composição química. Os resultados mostraram que a farinha de casca de banana se destacou pelos maiores teores de proteínas, fibras, lipídios, cinzas, fenóis totais, flavonoides totais e atividade antioxidante, o que torna esta farinha eficaz como aditivo funcional. Porém, os resultados das características físicas e sensoriais dos biscoitos mostraram que a variação na porcentagem de farinha de casca de banana levou a maiores alterações nos atributos de qualidade dos biscoitos, portanto, o percentual de inclusão deve ser limitado. A farinha de polpa de banana (UBF) tinha alto teor de amido, contudo, os biscoitos produzidos com maiores percentuais dessa farinha e menores porcentagens de amido de mandioca apresentaram menores taxas de propagação, maior dureza e menor aceitação sensorial, mostrando a importância da matéria prima amilácea nas propriedades físicas de biscoitos. Formulações contendo amido de mandioca misturado com até $15 \%$ de farinha de banana (1:1, polpa e casca) são uma boa base para biscoitos sem glúten.

Palavras-chave: Farinha de frutas. Amido. Celíacos. Aceitação sensorial.

\section{Introduction}

The gluten-free food market has shown significant increase in recent years. Purchasing gluten-free products is not only associated with gluten allergy but also to product concepts that are beneficial to health and help with weight loss (Masure, Fierens, \& Delcour, 2016; Witczak, Ziobro, Juszczak, \& Korus, 2016; Brunatti, Garcia, Mischan, \& Leonel, 2018). Xu, Zhang, Wang and Li (2020) in their review about the gluten-free biscuits and cakes reported that is estimated that the market for gluten-free products will increase from $\$ 4.18$ billion in 2017 to $\$ 6.47$ billion in 2023.

Biscuits have great commercial expression because they are widely accepted, affordable and have a long shelf life (Iwegbue,
2012). The world production of biscuits is 18.95 million tons, and Brazil is the fourth largest biscuits market in the world, with a production of more than 1.68 million tons in 2016, of which 265 thousand tons were of dry biscuits/sweets. In the same year, the national consumption of biscuits was $8.2 \mathrm{~kg} /$ per capita/year and with the expectation that in the coming years the Brazilian will increase the consumption driven by launches and adjustments of products to the market, following the trend of healthier products (Associação Brasileira das Indústrias de Biscoitos, Massas Alimentícias e Pães \& Bolos Industrializados [ABIMAPI], 2018).

In addition to these market characteristics, in the production of glutenfree products, biscuits show some advantages, since gluten plays a minor role in biscuits so a wider variety of flours might be employed (Di 
Cairano, Galgano, Tolve, Caruso, \& Condelli, 2018). However, several points must be considered before developing products for celiac patients. Some of the considerations include excluding all possible raw materials containing gluten, selecting an alternative flour source, obtaining acceptable texture and color in the product, improving the nutritional quality of the product, as well as knowing the need for product safety and specific labeling (Jnawali, Kumar, \& Tanwar, 2016).

Mixtures of ingredients are useful to obtain an appealing biscuit since each ingredient can provide a specific effect on dough and final product. Added this, in view of environmental sustainability and the reduction of food waste, a new trend is the use of agroindustrial by-products in the formulation of gluten-free biscuits (Di Cairano et al., 2018). Based in these aspects, it is possible to consider the cassava starch and the banana pulp and peel flours as potential ingredients for biscuits production, due to their technological and nutritional characteristics, as well as their cultural, nutritional and economic importance for the Brazil.

Brazil occupies a prominent position in the world production of cassava with production of 19.39 million tons, which is distributed in almost all states of the country (Food and Agriculture Organization of the United Nations [FAO], 2019). Cassava starch production in the country has been growing significantly in recent decades, from 170 thousand tons in 1990 to 616 thousand tons in 2016 , with the volume produced being almost entirely absorbed in the country and the food industry representing $22.8 \%$ of purchases (Leonel et al,. 2015).

Cassava starch has some important characteristics that make it suitable for special uses in food products. It has good thickening and textural qualities, forms a clear gel with good stability and low setback (Anggraini, Sudarmonowati, Hartati, Suurs, \& Visser, 2009). This starch also has been widely used in many bakery products because of its low amylose content and differential physicochemical characteristics (swelling capacity and color) when compared to other starches (Saeleaw \& Schleining, 2010; Nawaz et al., 2021).

Banana production accounting for $16 \%$ of the total fruit production worldwide (107.4 million tons), with $61.16 \%$ of world production originating from India (25.67\%), China (11.24\%), Philippines (8.04\%), Brazil (6.41\%) and Ecuador (5.57\%). Brazil is the fourth largest world producer, with production of 6.89 million tons in an area of approximately 485 thousand hectares (FAO, 2019).

Banana grows in hanging bunches, with three to twenty hands per bunch and almost twenty fruits per hand. The fruit weight is about $125 \mathrm{~g}$ with $25 \%$ dry matter. This fruit is characterized by its high starch content in the green phase of ripening and also by the presence of bioactive compounds with antioxidant and chelating properties, such as phenolic compounds, carotenoids, ascorbic acid, flavonoids, biogenic amines and some phytosterols (Pathak, Mandavgane, \& Kulkarni, 2017).

Owing to excess banana production, large volumes of bananas are wasted annually in the main producing regions. This fact coupled with the important nutritional aspects has motivated the food industry to process unripe fruits for flour production. However, when industrial processing of green bananas for flour increases, the residual peel volume needs to be considered. Peels are considered to represent $35 \%$ to $40 \%$ of the 
total weight of banana fruits, with variations between cultivars. Peels have high levels of fibre, phenolic compounds and compounds with antioxidant activities, which also make them a raw material of great interest for the development of food products (Vu, Scarlett, \& 2018; Khoozani, Birch, \& Bekhit, 2019).

Therefore, this study aimed to develop a gluten-free biscuit using cassava starch in mixtures with banana pulp and peel flours and evaluating the effects of different formulations on the physical characteristics and sensory acceptance of the biscuits.

\section{Material and Methods}

\section{Production of banana flours}

For the production of banana flours ten bunches of the mother plant of cultivar Nanicão were harvested (350 days after planting) with fruits of all green peel (ripening stage 1). The banana fingers were peeled, and the pulp and peel separated. The pulps were sliced (10 $\mathrm{mm}$ ) and immersed in sodium metabisulphite solution $\left(0.25 \mathrm{~g} \mathrm{~L}^{-1}\right)$ for 15 minutes and then dehydrated in an air circulation oven at $50^{\circ} \mathrm{C}$ for 48 hours. The peels were sanitized in chlorinated water (150 ppm for 15 minutes) and then dehydrated in an air circulation oven at $50^{\circ} \mathrm{C}$ for 72 hours. The dehydrated materials were ground to obtain the unripe banana pulp flour (UBF) and banana peel flour (BPeF).

\section{Biscuits production}

In the biscuits formulations were used wheat flour, unripe banana pulp flour (UBF), unripe banana peel flour (BPeF), and cassava starch (CS). They were characterized following American Association of Cereal Chemists [AACC] (2018) methods for moisture content (44-15.02), protein (46-10.01), lipids (3025.01), total dietary fiber (32-10.01), total sugars (80-60.01), starch (76-13.01) and ash (08-12.01). Banana flours were also analyzed for resistant starch (32-40.01), total phenolic and total flavonoids contents and antioxidant activity (DPPH free radical scavenging) as described by Borges et al. (2020).

In the production of the biscuits, the ingredients were weighed individually. In a mixer were added margarine, sugar and vanilla essence in the proportions described in Table 1 and these ingredients were mixed at low speed for 5 minutes until a cream was obtained. In a "Y" mixer, the starchy materials were mixed for 5 minutes and then added to the cream in the mixer, maintaining agitation for another 5 minutes. The dough was removed and molded manually into spheres of $3 \mathrm{~cm}$ in diameter and uniform thickness. The trays with the uncooked material were left in the freezer for 30 minutes and then the biscuits were baked in an electric oven with a controlled temperature of $180^{\circ} \mathrm{C}$ for 20 minutes. The oven conditions were always the same for all samples. After baking the biscuits were left at room temperature until cooling, wrapped and stored in sealed polypropylene packaging. 
Table 1

Ingredients for biscuits preparation

\begin{tabular}{|ccccccccc|}
\hline & \multicolumn{7}{c}{ Formulations } \\
\hline Ingredients (\%) & F1 & F2 & F3 & F4 & F5 & F6 & F7 & F8 \\
\hline Wheat flour (WF) & 38 & - & - & - & - & - & - & - \\
Banana pulp flour (UBF) & - & 3.5 & 5.5 & 7.5 & 9.5 & 27 & 23 & 19 \\
Banana peel flour (UBPF) & - & 3.5 & 5.5 & 7.5 & 9.5 & 5.5 & 7.5 & 9.5 \\
Cassava starch (CS) & - & 31 & 27 & 23 & 19 & 5.5 & 7.5 & 9.5 \\
Margarine & 34 & 34 & 34 & 34 & 34 & 34 & 34 & 34 \\
Sugar & 27 & 27 & 27 & 27 & 27 & 27 & 27 & 27 \\
Vanilla essence & 1 & 1 & 1 & 1 & 1 & 1 & 1 & 1
\end{tabular}

\section{Biscuits analysis}

In assessing the quality of biscuits, several dimensional indices can be measured in order to evaluate the extent of changes that occurred during baking. The diameter and thickness of the biscuits were measured using a digital caliper on a set of twelve biscuits. Spread ratio was calculated as the ratio between diameter and thickness of baked biscuits, according to the AACC method 1050.05 (AACC, 2000).The spread factor of each banana / cassava biscuit compared to the wheat biscuit was calculated using the ratio of the spreading rate of the sample and the spreading rate of the control sample multiplied by 100 .

Specific volume (SV) of the biscuits was determined according to the mass displacement method (millet seed) using a graduated cylinder (Method 10-05.01) (AACC, 2000).

The texture of the baked biscuits was evaluated at TA.XT plus texture analyzer (Stable Micro Systems, Surrey, Inglaterra), using the Exponent Stable Micro Systems software. Hardness were measured by compressing biscuits with a $36 \mathrm{~mm}$ diameter cylindrical probe and pre-test, test and posttest speeds were set at 2.0,2.0, and $3.0 \mathrm{~mm}$ $\mathrm{s}^{-1}$, respectively (Jia et al., 2020).

The color measurements of the biscuits were performed in a colorimeter Minolta CR-300 (Minolta Co., Japan) with standard illuminant $D_{65}$. The parameters analyzed were L* [0 (black) to 100 (white)], a* [-60 (greenness) to +60 (redness)], b* [-60 (blueness) to +60 (yellowness)]. The browning index (BI) was calculated as described by Sung \& Chen (2017). The color difference $\left(\Delta \mathrm{E}^{*}\right)$ between the wheat biscuit and the gluten-free biscuits was calculated as described by Laguna, Salvador, Sanz, \& Fiszman (2011).

\section{Sensory acceptance}

Sensory characteristics of biscuits were evaluated for different sensory attributes by a group of panelists recruited among students at the São Paulo State University, Brazil ( $n=60)$. Biscuits were coded with three random digits numbers and offered to panelists in monadic, balanced and random order. Panelists drank mineral water between 
evaluating different samples for mouth cleaning. Acceptance testing was carried out using a nine point hedonic scale in the following sequence: 1 - dislike extremely, 2 dislike very much, 3 - dislike moderately, 4 dislike slightly, 5 - neither like nor dislike, 6 - like slightly, 7 - like moderately, 8 - like very much and 9 - like extremely (Meilgaard, Carr, \& Civille, 2006). The parameters evaluated were overall appearance, color, crispness and taste. The study was approved by the Ethics Committee (CAAE: 79844717.0.0000.5411).

\section{Statistical analysis}

Data are expressed as mean \pm standard deviation. The effect of formulations was evaluated by one-way ANOVA followed by Tukey's test using the SISVAR program (Ferreira, 2011). Differences were considered significant when $p<0.05$.

\section{Results and Discussion}

Chemical composition of wheat flour, banana flours and cassava starch

Soft wheat has unique properties, which makes it suitable for the production of biscuits, such as relatively lower protein content (8-11\%) and more mellow gluten properties than hard wheat (Pareyt \& Delcour,
2008). Results showed that wheat flour had high protein content (9.5\%) (Table 2). The other components of this flour had levels similar to those obtained by Kim and Kim (2017), except for the fibre content, which was lower than that reported by the authors. This difference may be related to the amount of bran in wheat flour.

Cassava starch had high starch content (86.96\%) and low contents of other components (Table 2). The levels obtained in this study are within the chemical composition variations cited by Zhu (2015) in your paper review on cassava starch. According to this author the ranges of ash, protein, lipid, and fibre contents in cassava starch are $0.03 \%$ - $0.29 \%, 0.06 \%-0.75 \%, 0.01 \%-1.20 \%$, and $0.11 \%-1.90 \%$, respectively.

The composition of banana pulp flours is very varied, being mainly influenced by the cultivar used, the stage of ripening of the fruit and type of processing. Results showed that banana pulp flour (UBF) contained $8.02 \%$ of moisture and high starch (80.5\%) and ash (2.34\%) contents and low lipid (0.65\%) level when compared with wheat flour (Table 2). These characteristics were also observed in other studies with banana flour. Savlak, Türker and Yesilkanat (2016) cited moisture ranges from 8.75 to $9.19 \%$ and Bi et al. (2017) reported ranges of ash, lipids, protein, and starch of $2.30 \%-2.79 \%, 0.35 \%-0.57 \%, 2.90 \%-4.59 \%$, $78.19 \%-81.82 \%$, respectively. 
Table 2

Chemical compositions of wheat flour, cassava starch, flours from peel and pulp of banana and calculated composition of mixtures

\begin{tabular}{|c|c|c|c|c|c|c|c|}
\hline & \multicolumn{7}{|c|}{ Compositions of starchy materials } \\
\hline & \multicolumn{2}{|c|}{ Wheat flour } & \multicolumn{2}{|c|}{ Cassava starch } & $\begin{array}{l}\text { Banana pulp } \\
\text { flour (UBF) }\end{array}$ & \multicolumn{2}{|c|}{$\begin{array}{l}\text { Banana peel } \\
\text { flour (BPeF) }\end{array}$} \\
\hline Moisture $\left(\mathrm{g} 100 \mathrm{~g}^{-1}\right)$ & \multicolumn{2}{|c|}{$11.9 \pm 0.32$} & \multicolumn{2}{|c|}{$12.2 \pm 0.23$} & $8.02 \pm 0.43$ & \multicolumn{2}{|c|}{$8.10 \pm 0.11$} \\
\hline Ash $\left(g 100 g^{-1}\right)$ & \multicolumn{2}{|c|}{$0.44 \pm 0.03$} & \multicolumn{2}{|c|}{$0.1 \pm 0.02$} & $2.34 \pm 0.04$ & \multicolumn{2}{|c|}{$6.14 \pm 0.16$} \\
\hline Protein $\left(\mathrm{g} 100 \mathrm{~g}^{-1}\right)$ & \multicolumn{2}{|c|}{$9.5 \pm 0.19$} & \multicolumn{2}{|c|}{$0.07 \pm 0.01$} & $3.21 \pm 0.26$ & \multicolumn{2}{|c|}{$7.06 \pm 0.38$} \\
\hline Lipids (g 100g-1) & \multicolumn{2}{|c|}{$1.0 \pm 0.10$} & \multicolumn{2}{|c|}{$0.23 \pm 0.02$} & $0.65 \pm 0.02$ & \multicolumn{2}{|c|}{$2.89 \pm 0.06$} \\
\hline Fibre $\left(\mathrm{g} 100 \mathrm{~g}^{-1}\right)$ & \multicolumn{2}{|c|}{$0.35 \pm 0.08$} & \multicolumn{2}{|c|}{$0.15 \pm 0.02$} & $1.96 \pm 0.28$ & \multicolumn{2}{|c|}{$11.35 \pm 0.31$} \\
\hline Total sugar (g 100g-1) & \multicolumn{2}{|c|}{$1.7 \pm 0.11$} & \multicolumn{2}{|c|}{$0.14 \pm 0.01$} & $3.32 \pm 0.04$ & \multicolumn{2}{|c|}{$3.01 \pm 0.12$} \\
\hline Starch $(g$ 100g-1) & \multicolumn{2}{|c|}{$75.2 \pm 1.59$} & \multicolumn{2}{|c|}{$86.96 \pm 1.15$} & $80.50 \pm 0.82$ & 61. & \pm 0.27 \\
\hline Resistant starch (\%) & & & $1.1 \pm 0$. & & $66.19 \pm 1.87$ & 49 & $2 \pm 0.93$ \\
\hline Total phenolic (mg GAE/100g) & & & - & & $33.5 \pm 1.07$ & 17 & $3 \pm 4,10$ \\
\hline Total flavonoids $(\mu \mathrm{g} / 100 \mathrm{~g})$ & & & - & & $1331 \pm 163.80$ & 480 & $\pm 263,9$ \\
\hline Antioxidant activity (\%) & & & - & & $13.8 \pm 1.43$ & & \pm 1.45 \\
\hline & & & alculated c & npositio & on of mixtures & & \\
\hline & $\mathrm{F} 2$ & F3 & $\mathrm{F} 4$ & F5 & $\mathrm{F} 6$ & F7 & F8 \\
\hline Moisture $\left({\left.\mathrm{g} 100 \mathrm{~g}^{-1}\right)}\right.$ & 11.37 & 10.95 & 10.53 & 10.12 & 8.62 & 8.84 & 9.06 \\
\hline Ash $(g$ 100g-1) & 0.93 & 1.34 & 1.76 & 2.17 & 2.57 & 2.65 & 2.73 \\
\hline Protein $\left(\mathrm{g} 100 \mathrm{~g}^{-1}\right)$ & 1.08 & 1.59 & 2.10 & 2.60 & 3.32 & 3.35 & 3.39 \\
\hline Lipids (g 100g-1) & 0.56 & 0.72 & 0.87 & 1.02 & 0.94 & 1.03 & 1.12 \\
\hline Fibre $(g$ 100g-1) & 1.45 & 2.10 & 2.75 & 3.40 & 3.10 & 3.48 & 3.86 \\
\hline Total sugar (g 100g-1) & 0.75 & 1.05 & 1.35 & 1.65 & 2.80 & 2.62 & 2.45 \\
\hline Starch $(g$ 100g-1) & 83.74 & 82.15 & 80.55 & 78.96 & 78.63 & 77.99 & 77.36 \\
\hline Resistant starch (\%) & 4.39 & 6.66 & 9.16 & 11.2 & 20.65 & 19.02 & 17.38 \\
\hline Total phenolic (mg GAE/100g) & 7.46 & 11.72 & 15.99 & 20.26 & 18.93 & 21.18 & 23.44 \\
\hline Total flavonoids $(\mu \mathrm{g} / 100 \mathrm{~g})$ & 214.86 & 337.64 & 460.42 & 583.20 & 623.81 & 666.73 & 709.65 \\
\hline Antioxidant activity (\%) & 2.37 & 3.72 & 5.08 & 6.43 & 6.69 & 7.22 & 7.74 \\
\hline
\end{tabular}

Values calculated based on the proximate composition of each ingredient and its contribution to the final formulation.

Menezes et al. (2011) also evaluating chemical composition and nutritional value of unripe banana flour (Musa acuminata, cultivar Nanicão) cited values of $3.60 \%$ for protein, $3.14 \%$ for ash, $0.89 \%$ for lipids, $1.81 \%$ for total soluble sugars, $76.77 \%$ for total starch and $7.20 \%$ for dietary fibre (dry basis). Sardá et al. (2016), also studying unripe banana flours produced from cultivar Nanicão, as well as commercial products, reported ranges from $4.14 \%$ to $10.60 \%$ for moisture, $0.00 \%$ to $5.79 \%$ for protein, $0.06 \%$ to $2.08 \%$ of lipids and $0.35 \%$ to $5.17 \%$ of ash (wet basis). These studies show results close to those obtained in this study, however, higher levels for fibres and ashes are reported. 
Banana peel flour (BPeF) showed higher levels of fibre (11.35\%), lipids (2.89\%) and ash (6.14\%) (Table 2), which makes this flour effective as a functional additive. The high ash content in banana peel flour (4.27\%) was also observed by Sardá et al. (2016). This result shows that the flour obtained from the green banana peel can be a good vehicle to increase the amount of minerals present in the biscuits, which can be valuable in the treatment of deficiencies caused by certain pathologies like celiac disease.

The high fibre content obtained in banana peel flour (11.35\%) (Table 2) was very similar to that reported by Eshak (2016), which shows the potential of this flour for the treatment of intestinal constipation and also in the treatment of other diseases such as cardiac disease and diabetes.

For bioactive compounds, the results observed in this study (Table 2) were similar to those observed by Fatemeh, Saifullah Abbas and Azhar (2012), who reported wide variation in the values of TPC (total phenolic content), TFC (total flavonoid content) and antioxidant activity in banana pulps and banana peel flours. TPC ranged from 75.01 to $685.57 \mathrm{mg}$ GAE/100 g, TFC ranged from 39.01 to $389.33 \mathrm{mg} C E Q / 100 \mathrm{~g}$ of dry matter and the antioxidant activity ranged from $26.55 \%$ to $52.66 \%$. Similar of the results observed in this study, other works showed that banana peel include higher phenolic and flavonoids contents and antioxidant activity $(179.8 \mathrm{mg}$ GAE/ $100 \mathrm{~g}$ of TPC, $4808 \mu \mathrm{g} / 100 \mathrm{~g}$ TFC and $53.9 \%$ antioxidant activity) than that of banana pulps (33.5 mg GAE/100g of TPC, 1331 $\mu \mathrm{g} / 100 \mathrm{~g}$ TFC and $13.8 \%$ antioxidant activity) (Someya, Yoshiki, \& Okubo, 2002; Sulaiman et al., 2011; Fatemeh et al., 2012).
Green bananas are rich in resistant starch (RS), which is beneficial for colon health, with levels ranging from 17 to $48 \%$ (dry basis) (Khoozani et al., 2019). The content of resistant starch in green banana flour depends on the cultivar, the stage of ripeness, and the type of processing. Sardá et al. (2016) observed that the unripe banana flour and unripe banana peel flour produced in their study showed the RS content of $57.48 \%$ and $42.25 \%$ (d.w.), respectively, values that were similar to those found in this study (66.19\% and $49.52 \%)$.

These results of total phenolic compounds, flavonoids, antioxidant activity and resistant starch in banana flours (UBF and $\mathrm{BPeF}$ ) reinforce the potential of these flours in increasing the nutritional values of foods, which was also discussed by other authors in their studies on production, characterization and beneficial health effects of banana flours (Pathak et al., 2017; Vu et al., 2018; Khoozani et al., 2019; Borges et al., 2020).

\section{Biscuits analysis}

Biscuits comprise a matrix and their properties are mainly determined by the volume of air spaces and fat globules, as well as the level of homogeneity. Various dimensional indices can be measured in biscuits to assess the extent of thermal expansion during baking. The biscuits developed in the present study were round shaped, had an average mass, diameter and thickness of $7.2 \mathrm{~g}, 5.20 \mathrm{~cm}$ and $0.98 \mathrm{~cm}$, respectively (Figure 1).

During the baking process, the biscuit diameter increases linearly during the first few minutes until it reaches a maximum value and then remains fixed or slightly decreases. Diameter of the biscuits ranged from 45.25 to 
$58.67 \mathrm{~cm}$. Regardless of the ingredients of the formulations, gluten-free biscuits increased in diameter more than the control biscuit (except F6 and F7), which had also been found by
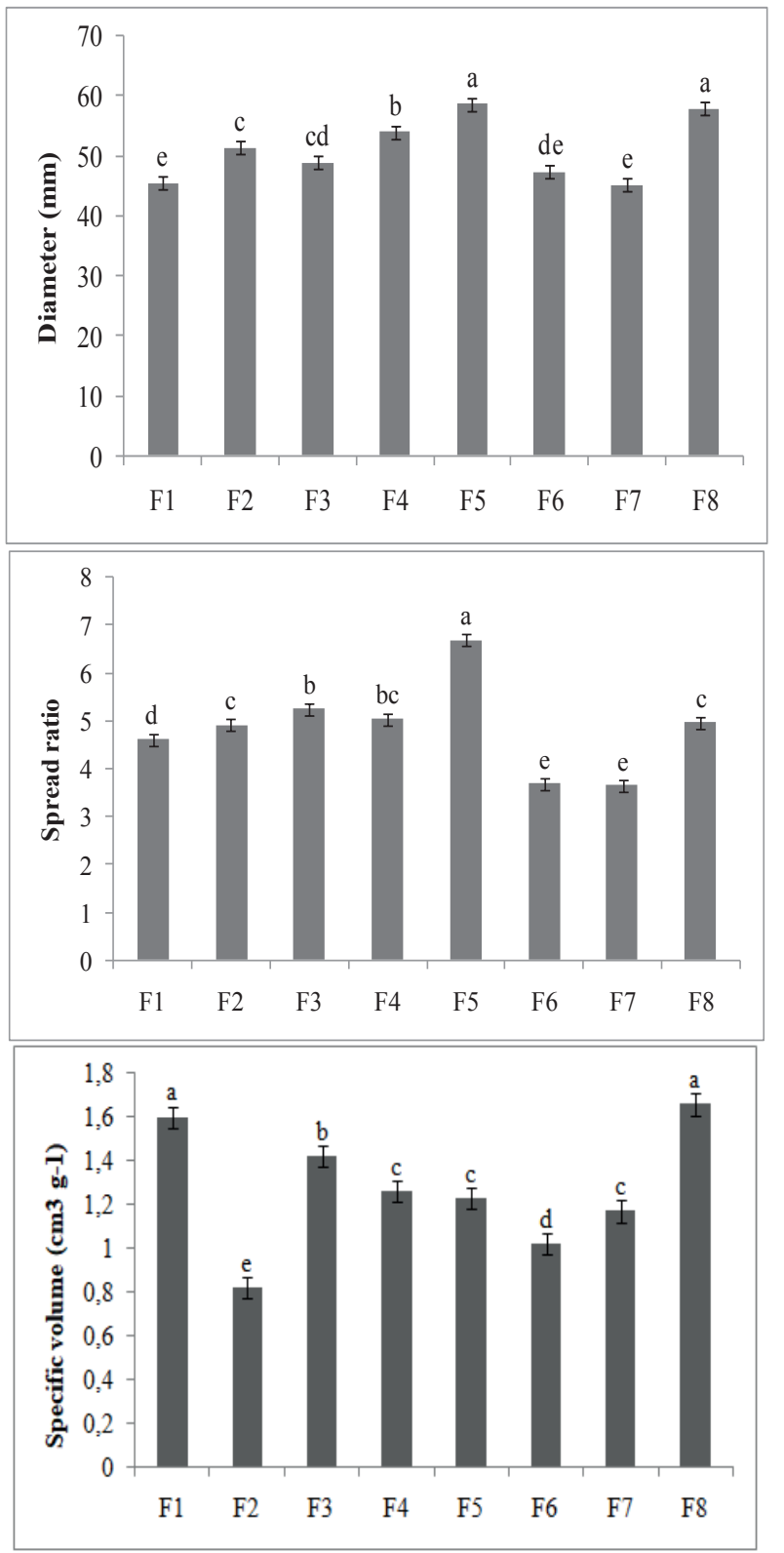

Figure 1. Physical properties of biscuits.
Hossain et al. (2017). The largest diameters were observed in biscuits obtained from formulations with lower starch contents (F5 and F8 - lower percentages of UBF and CS).
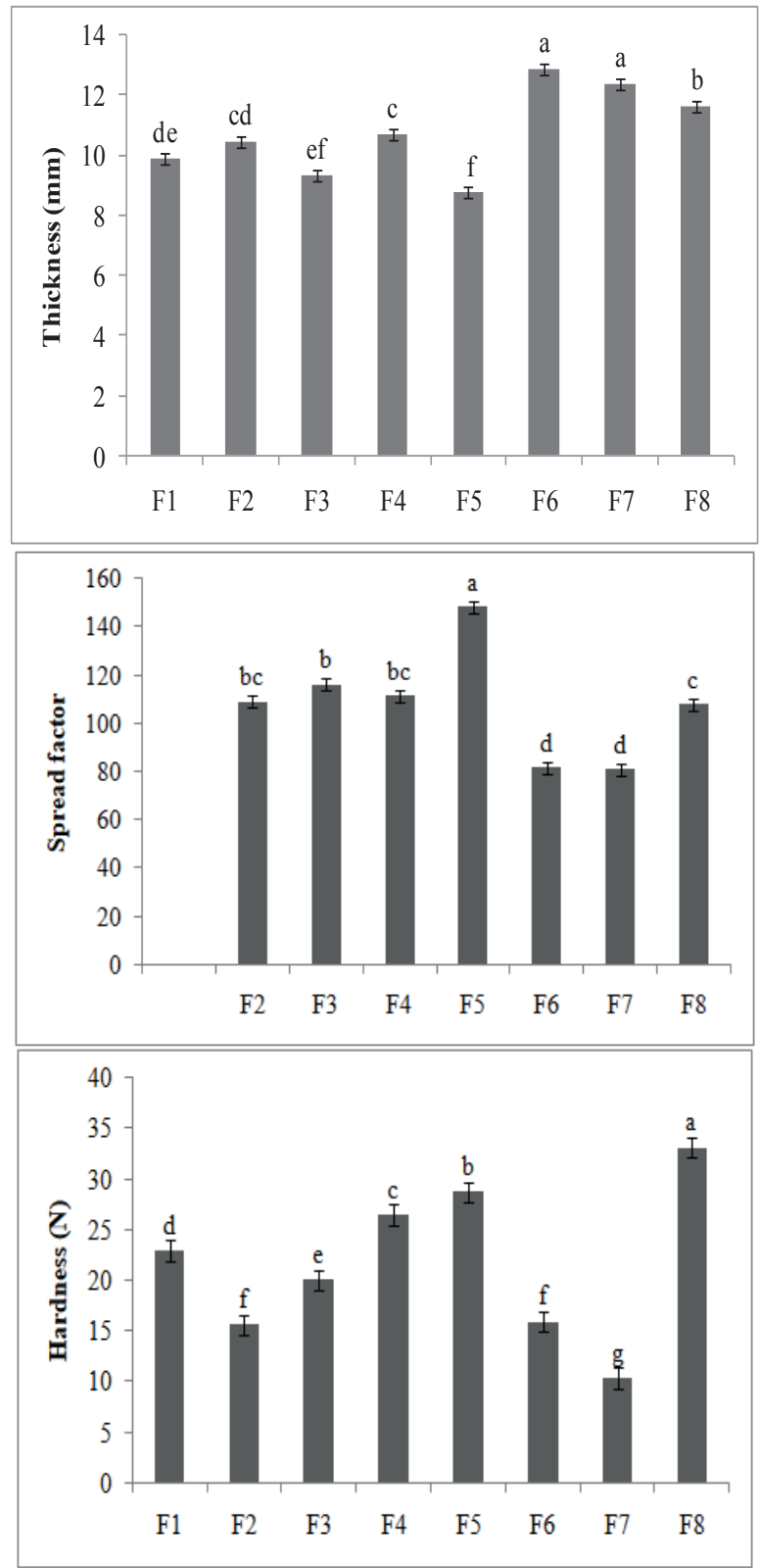
The biscuits of formulations F6 and F7 did not differ from the control (F1) for this parameter, however showed significant differences in relation to the biscuits of formulations F4 and F5, showing an inverse effect of unripe banana flour and cassava starch for this parameter. This result can be related to the characteristics of the starches from banana and cassava (Mesquita et al. 2016; Zhu, 2015). In addition, the higher fibre content in banana pulp flour may also have interfered with this result. The dietary fibre retains large amounts of water, affecting the viscosity of the dough. If the viscosity of the dough increases, a decrease in the maximum diameter is expected (Serial et al., 2016).

Regarding the thickness of the biscuits, it was observed that the products obtained from the formulations with the lowest amounts of cassava starch and the largest amounts of unripe banana flour (F6 to F8) had the highest thickness.

Spread ratio is used to determine the quality of flour used in preparing biscuits and the ability of the biscuit to rise. The resulting degree of spread in the final biscuit diameter is controlled by the spread ratio and the set time. The set time is determined by the water level in the dough that is free to act as a solvent and the strength of the dough. In addition, the spread ratio is also influenced by the waterbinding components of the dough (Bala, Gul, \& Riar, 2015).

Increasing the percentage of cassava starch in the formulations increased the spread ratio and spread factor of biscuits, with the highest spread ratio observed in biscuits of formulation F5. Higher spread factor is considered a positive biscuit characteristic. Additionally, the significant decrease in the percentage of cassava starch coupled with the increase in fibre content in formulations F6 and F7 may have contributed to the lower spread ratio of biscuits. This effect may have occurred due to greater hygroscopicity of the fibrous materials present in banana flour, which retain water, giving greater consistency to the dough. Besides this, fibrous fragments disrupt the starchy film of air cell walls, reducing their formation and swelling and altering air cell size. On the other hand, higher protein content in the dough may also be related to lower spread ratio as observed by Nasir et al. (2010).

Except for biscuits of formulations F6 and F7, all gluten-free biscuits had a higher spread ratio when compared to the wheat biscuit (F1), which was also observed by Sharma, Saxena and Riar (2016). The low spread ratio value of the control sample shows that starch polymer molecules in wheat flour are highly bound with the granules and swelling is limited when heated (Mahloko, Silungwe, Mashau, \& Kgatla, 2019).

The volume expansion phenomena basically depend on the viscous and elastic properties of the dough. Specific volumes ranged from 0.82 to $1.66 \mathrm{~mL} \mathrm{~g}^{-1}$. These values were similar to those observed by Feddern, Durante and Miranda (2011) in their study with wheat and rice bran biscuits (1.20 to $1.65 \mathrm{~mL} \mathrm{~g}^{-1}$ ). Data analysis showed no difference between control biscuits and F8 biscuits, and the lowest specific volume was observed in F2 biscuits. These results may be related to the protein content present in the formulations. Protein has a strong effect on the water absorption properties of the flour when preparing dough (Pareyt \& Delcour, 2008). 
Texture is an important biscuit quality parameter determined by the application of breakage force. The hardness values were ranging from 10.35 to $33.13 \mathrm{~N}$. Data analysis showed an increase in biscuits hardness with increasing percentages of banana flours mixed with cassava starch (F2 to F5), and the highest hardness were observed in F8 biscuits. These changes may be related to the increase in fibre and sugar content in the formulations. Fibre consists of single polysaccharide chains that can interact with each other to form junction zones which can enclose large amounts of strongly bound and fairly static water. This phenomenon increases the fibre diameter in the junction zones and reduces the tendency for the water to exit the cavities, reinforcing the biscuit matrix. So, biscuits with higher fibre content are harder and more compact (Laguna et al., 2011). Sugar is considered a key ingredient in the production of biscuits because it promotes direct changes in the texture, color and expansion factor of this product. The texture of gluten-free biscuits does not depend on protein/starch structure, but primarily on starch gelatinization and super cooled sugars (Thejasri, Hymavathi, \& Roberts, 2017; Plazzotta, Sillani, \& Manzocco, 2018).

Colour is an important attribute in food products as it can stimulate an individual's appetite. In addition, color is one of the parameters used for process control during cooking and roasting, as brown pigments appear as browning and caramelization reactions occur (Pereira, Correia, \& Guine, 2013; Maina, 2018). Measurement of the upper surface colour of the biscuits showed significant difference between biscuits produced from gluten-free formulations as well as compared with the control biscuit.

Biscuits from $\mathrm{F} 1$ and $\mathrm{F} 2$ are in the bright zone, with lightness values $\left(L^{*}\right)$ above 50 (Figure 2). However, for all samples $a^{*}$ values were positive, indicating the predominance of red over the green. The $b^{*}$ coordinate also assumed positive values, indicating a predominance of yellow coloration. 

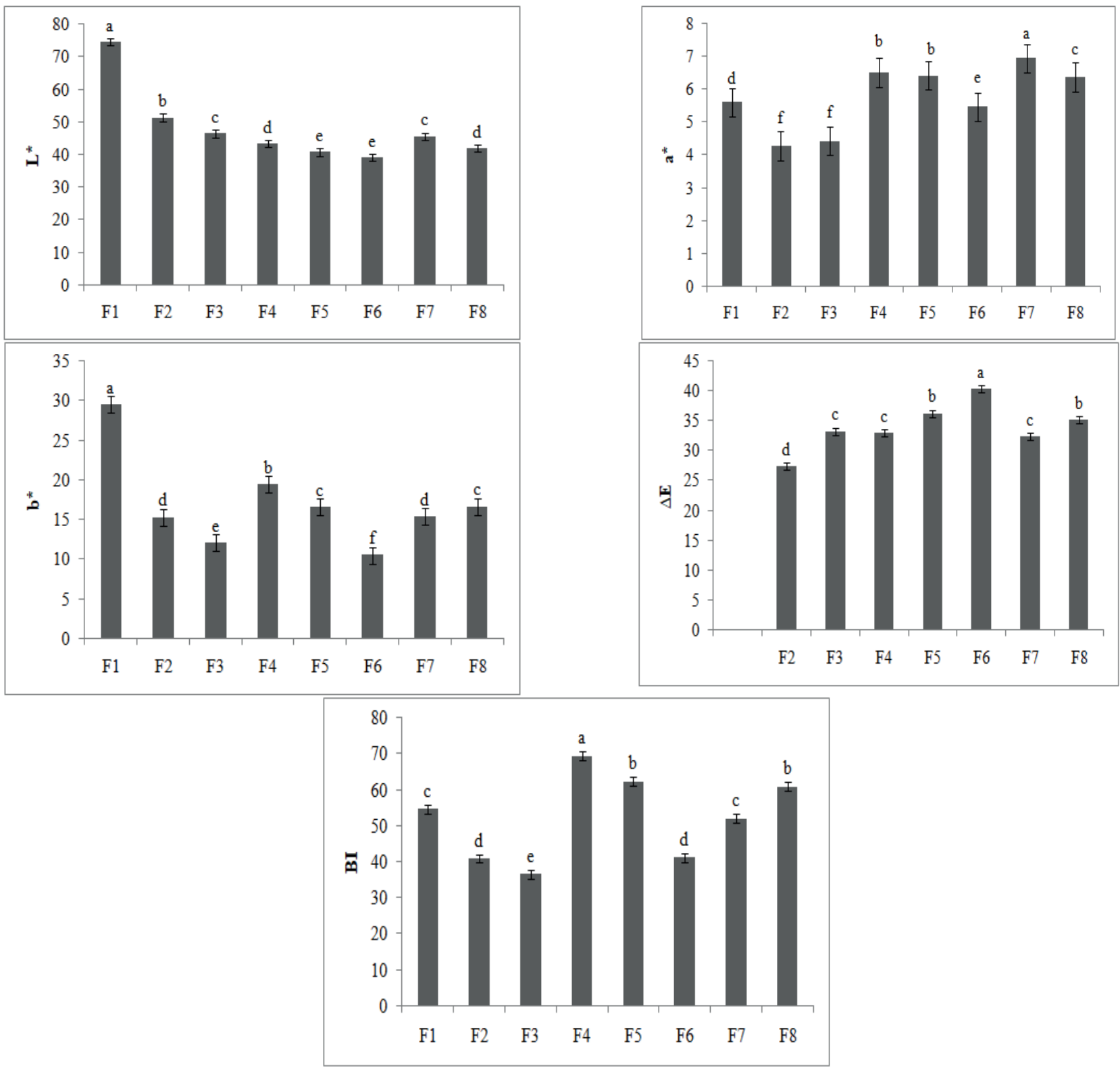

Figure 2. Colour properties of biscuits.

Results showed that there was a decline in biscuits luminosity $\left(L^{*}\right)$ regardless of formulation when compared to control biscuits (F1). In addition, with the increase in the percentage of banana flours in the formulations there was a significant decline in lightness with increased redness (a* positive).
Higher values of $a^{*}$ (red shift) indicate darker crust. The biscuits of the control formulation had higher $b^{*}$ (yellow), with a decrease in this colour component in the gluten-free biscuits (Figure 2). Thus, the colour of the biscuits ranged from creamy yellow to dark brown. 
Results showed that biscuits of F6 showed higher colour difference values $(\triangle \mathrm{E})$ and browning index $(\mathrm{BI})$. The increased inclusion of banana flours in the formulations led to a higher percentage of sugars and protein, which contributed to the darkening of biscuits (Pereira et al., 2013).

The high colour difference value $(\Delta \mathrm{E})$ and browning index (BI) in biscuits are due to the ingredient composition and red pigmentation resulting from the Maillard reaction or nonenzymatic browning which depends on the content of reducing sugars and amino acids or proteins on the surface, baking temperature, and time (Purlis, 2010; Pereira et al., 2013).

In bakery products, sugars content and the type of sugar are the main variables affecting colour formation. In general, hydroxymethylfurfural (HMF) formation is increased with sugars content and at oven temperatures, sucrose presents stability and then glucose and fructose produce more HMF (Purlis, 2010).

So, the inclusion of green banana flours led to the addition of complex ingredients to the dough leading to various interactions between proteins, starches, fibres, lipids and smaller compounds, which led to several changes in physical properties of biscuits.

\section{Sensorial acceptance}

Increasing numbers of consumers are looking for food products with functional properties to maintain and improve their health. The use of derivatives of banana and cassava might be one of the effective ways to meet consumer's demand considering that banana and cassava have been globally consumed as staple foods. Consumer perceptions have been recognized as a key factor to negotiate market opportunities for development of products. Furthermore, ready-to-eat processed foods of longer shelf life, satisfying taste, texture, and high nutritive value seem to be the most important products that can satisfy consumers (Duta \& Culetu, 2015).

Comparisons of the mean liking scores for the sensory attributes of the biscuits are shown in Figure 3. All the acceptance descriptors showed significant differences among the samples. The sensory evaluation of the biscuits showed that all formulations had hedonic scores greater than 5 (indifferent) for all the analyzed parameters, highlighting the good acceptance for the crispness. 

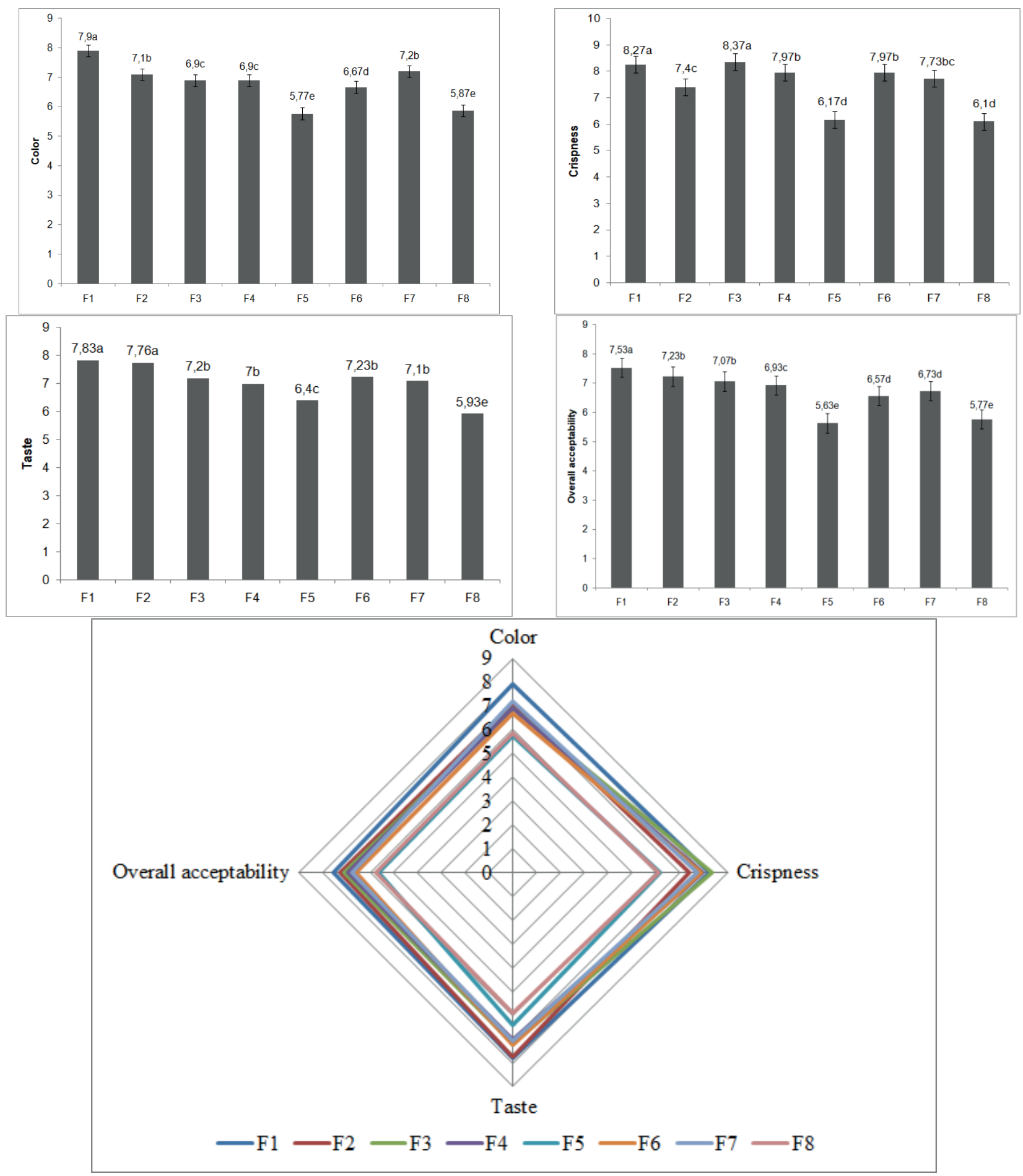

Figure 3. Hedonic scores for the sensory attributes of biscuits and radar graph. 
The F2 formulation was the one with the highest scores, probably because it was the one that used the lowest amounts of banana flours. The increase in the percentages of banana flour mixed with cassava starch in total substitution for wheat flour in biscuit formulations led to lower levels of sensory acceptance (F2 to F5). In addition, the use of a higher percentage of banana peel flour and a lower percentage of cassava starch negatively affected the sensory acceptance of biscuits as shown by the results of formulation F8.

The taste of the biscuits showed a drastic reduction in acceptance when it was used $19 \%$ of banana pulp flour (F8) compared to the formulation with $19 \%$ of cassava starch (F5). The reduction in the colour acceptance of the biscuits was more expressive in formulations F7 and F8, where the highest percentages of banana flour were used (Figure $3)$. Thus, the analysis of sensory acceptance indicated that the use of mixtures of banana flours in the percentages 1:1 (UBF and BPeF) up to $15 \%$ (F2 to F4) led to the production of biscuits with good acceptance rates.

\section{Conclusion}

The chemical composition of cassava starch, banana pulp flour and banana peel flour showed that banana flours are important source of nutrients beneficial to health, presenting high levels of resistant starch, total phenolic compounds, total flavonoids and antioxidant activity. The variation in the percentages of starchy materials in gluten-free biscuit formulations led to changes in physical and sensory characteristics. Banana peel flour had a more pronounced effect on biscuits characteristics Cassava starch proved to be better as a starch base than banana pulp flour.
Gluten-free biscuits with desired attributes of physical and sensory quality were obtained with formulations containing $23 \%$ to $31 \%$ of cassava starch and $7.5 \%$ to $3.5 \%$ of each banana flour (UBF and UBPeF).

\section{Acknowledgment}

The authors would like to thank the support of CNPq, Brazil (Processes 303373/2014-8, 302827/2017-0, 304455/ 2017-2).

\section{References}

American Association of Cereal Chemists (2000). Approved methods of analysis, methods 10-50.05 spread factor; 1005.01 (10nd ed.). Retrieved from http:// methods.aaccnet.org/default.aspxx

American Association of Cereal Chemists (2018). Approved methods of analysis, methods 08-01.01 ash-basic method; 44-15.02 moisture-air-oven methods; 4630.01 crude protein-combustion method; 76-13.01 total starch assay procedure (megazyme amyloglucosidase/alphaamylase method) (11nd ed.). Retrieved from http://methods.aaccnet.org/default. aspxx

Anggraini, V., Sudarmonowati, E., Hartati, N. S., Suurs, L., \& Visser, R. G. F. (2009). Characterization of cassava starch attributes of a different genotypes. Starch, 61(8), 472-481. doi: 10.1002/star. 200800121

Associação Brasileira das Indústrias de Biscoitos, Massas Alimentícias e Pães \& Bolos Industrializados (2018). Biscoitos- 
estatística. Recuperado de https://www. abimapi.com.br/estatisticas-biscoitos. php

Bala, A., Gul, K., \& Riar, C. S. (2015). Functional and sensory properties of cookies prepared from wheat flour supplemented with cassava and water chestnut flours. Cogent Food \& Agriculture, 1(1), 1-7. doi: 10.1080/23311932.2015.1019815

Bi, Y., Zhang, Y., Jiang, H., Hong, Y., Gu, Z., Cheng, L., Li, C. (2017). Molecular structure and digestibility of banana flour and starch. Food Hydrocolloids, 72(1), 219-227. doi: 10.1016/j.foodhyd.2017.06.003

Borges, C. V., Maraschin, M., Coelho, D. S., Leonel, M., Gomez, H. A. G., Belin, M. A. F.,... Lima, G. P. P. (2020). Nutritional value and antioxidant compounds during the ripening and after domestic cooking of bananas and plantains. Food Research International, 132 (6), 109061. doi: 10.10 16/j.foodres.2020.109 061

Brunatti, A. C. S., Garcia, E. L., Mischan, M. M., \& Leonel, M. (2018). Gluten-free puffed snacks of rice and cassava. Australian Journal of Crop Science, 12(2), 185-192. doi: 10.21475/ajcs.18.12.02.pne477

Di Cairano, M., Galgano, F., Tolve, R., Caruso, M. C., \& Condelli, N. (2018). Focus on gluten free biscuits: Ingredients and issues. Trends in Food Science \& Technology, 81(11), 203-212. doi: 10.1016/j.tifs. 2018. 09.006

Duta, D. E., \& Culetu, A. (2015). Evaluation of rheological, physicochemical, thermal, mechanical and sensory properties of oat-based gluten free cookies. Journal of Food Engineering, 162(1), 1-8. doi: 10. 1016/j.jfoodeng.2015.04.002
Eshak, N. S. (2016). Sensory evaluation and nutritional value of balady flat bread supplemented with banana peels as a natural source of dietary fiber. Annals of Agricultural Science, 61(2), 229-235. doi: 10.1016/ j.aoas.2016.07.002

Fatemeh, S. R., Saifullah, R., Abbas, F. M. A., \& Azhar, M. E. (2012). Total phenolics, flavonoids and antioxidant activity of banana pulp and peel flours: influence of variety and stage of ripeness. International Food Research Journal, 19(3), 1041-1046. Retrieved from http://www.ifrj.upm.edu. my/19\%20(03)\%202012/(35)\%20IFRJ \%2019\%20(03)\%202012\%20Azhar.pdf

Feddern, V., Durante, V. V. O., \& Miranda, M. Z. (2011). Physical and sensory evaluation of wheat and rice bran cookies. Brazilian Journal of Food Technology, 14(4), 267274. doi: 10.4260/BJFT2011140400032

Ferreira, D. F. (2011). SISVAR: a computer statistical analysis system. Ciência e Agrotecnologia, 35(6), 1039-1042. doi: 10.1590/S1413-70542011000600001

Food and Agriculture Organization of the United Nations (2019). FAOSTAT: production crop data. Retrieved from http://faostat.fao. org/site/\%20339/default.aspx

Hossain, A. K. M., Brennan, M. A., Mason, S. L., Guo, X., Zeng, X. A., \& Brennan, C. S. (2017). The effect of as taxanthin-rich microalgae "Haematococcus pluvialis" and whole meal flours incorporation in improving the physical and functional properties of cookies. Foods, 6(8), 57. doi: 10.3390/ foods 6080057

Iwegbue, C. M. A. (2012). Metal contents in some brands of biscuits consumed in Southern Nigeria. American Journal of 
Food Technolology, 7(3), 160-167. doi: 10. 3923/ajft.2012.160.167

Jia, M., Yu, Q., Chen, J., He, Z., Chen, Y., Xie, J.,... Xie, M. (2020). Physical quality and in vitro starch digestibility of biscuits as affected by addition of soluble dietary fiber from defatted rice bran. Food Hydrocolloids, 99(2), 105349. doi: 10.1016/j.fodhyd.2019.105349

Jnawali, P., Kumar, V., \& Tanwar, B. (2016). Celiac disease: overview and considerations for development of gluten-free foods. Food Science and Human Wellness, 5(4), 169176. doi: 10.1016/j.fshw.2016.09.0 03

Khoozani, A. A., Birch, J., \& Bekhit, A. E. A. (2019). Production, application and health effects of banana pulp and peel flour in the food industry. Journal of Food Science and Technology, 56(2), 548-559. doi: 10.1007/ s13197-018-03562-z

Kim, M. J., \& Kim, S. S. (2017). Utilisation of immature wheatflour as analternative flour with antioxidant activity and consumer perception on its baked product. Food Chemistry, 232(1), 237-244. doi: 10.1016/ j.foodchem.2017.04.007

Laguna, L., Salvador, A., Sanz, T., \& Fiszman, S. M. (2011). Performance of a resistant starch rich ingredient in the baking and eating quality of short-dough biscuits. LWT-Food Science and Technology, 44(3), 737-746. doi: 10.1016/j.Iwt.2010.05.034

Leonel, M., Feltran J. C., Aguiar, E. B., Fernandes, A. M., Peressin, V. A., Bicudo, S. J. (2015). Mandioca (Manihot esculenta Crantz). In: M. Leonel, A. M. Fernandes, C. M. L. Franco (Eds.), Culturas amiláceas: batata-doce, inhame, mandioca e mandioquinha-salsa (pp 183-326). Botucatu: CERAT /UNESP.
Mahloko, L. M., Silungwe, H., Mashau, M. E., \& Kgatla, T. E. (2019). Bioactive compounds, antioxidant activity and physical characteristics of wheat-prickly pear and banana biscuits. Heliyon, 5(10), e02479. doi: 10.1016/j.heliyon.2019.e02479

Maina, J. W. (2018). Analysis of the factors that determine food acceptability. The Pharma Innovation Journal, 7(5), 253-257. Retrieved from https://www. thepharmajournal.com/archives/2018/ vol7issue5/ PartD/7-4-84-339.pdf

Masure, H. G., Fierens, E., \& Delcour, J. A. (2016). Current and forward looking experimental approaches in gluten-free bread making research. Journal of Cereal Science, 67(1), 92-111. doi: 10.1016/j.jcs.2015.09.009

Meilgaard, M., Carr, B. T , \& Civille, G. V. (2006). Sensory evaluation techniques (4nd ed.). Boca Raton: CRC Press.

Menezes, E. W., Tadini, C. C., Tribess, T. B., Zuleta, A., Binaghi, J., Pak, N., \& Lajolo, F. M. (2011.) Chemical composition and nutritional value of unripe banana flour (Musa acuminata, var. Nanicão). Plant Foods for Hum Nutrition, 66(3), 231-237. doi: 10.1007/s11130-011-0238-0

Mesquita, C. B., Leonel, M., Franco, C. M. L., Leonel, S., Garcia, E. L., \& Santos, T. P. R. (2016). Characterization of banana starches obtained from cultivars grown in Brazil. International Journal of Biological Macromolecules, 89(8), 632-639. doi: 10. 1016/j.jibiomac.2016.05.040

Nasir, M., Siddiq, M., Ravi, R., Harte, J. B., Dolan, K. D., \& Butt, M. S. (2010). Physical quality characteristics and sensory evaluation of cookies made with added defatted maize germ flour. Journal of Food 
Quality, 33(1), 72-84. doi: 10.1111/j.17454557.2009.00291.x

Nawaz, A., Alhilali, A. H. T., Li, E., Khalifa, I., Irshad, S., Walayat, N.,... Tan, Z. Y. (2021). The effects of gluten protein substation on chemical structure, crystallinity, and $\mathrm{Ca}$ in vitro digestibility of wheat-cassava snacks. Food Chemistry, 339(1), 127875. doi: https://doi.org/10.1016/j.foodchem. 2020.127875

Pareyt, B., \& Delcour, J. A. (2008). The role of wheat flour constituents, sugar, and fat in low moisture cereal based products: a review on sugar-snap cookies. Critical Review in Food Science and Nutrition, 48(9), 824-839. doi: 10.1080/ 10408390701719223

Pathak, P. D., Mandavgane, S. A., \& Kulkarni, B. D. (2017). Fruit peel waste: characterization and its potential uses. Current Science, 113(3), 444-454. doi: 10.18520/cs/v113/ i03/444-454

Pereira, D., Correia, P. M., \& Guine, R. P. (2013). Analysis of the physical-chemical and sensorial properties of maria type cookies. Acta Chimica Slovaca, 6(2), 269280. doi: 10.2478/acs-2013-0040

Plazzotta, S., Sillani, S., \& Manzocco, L. (2018). Exploitation of lettuce waste flour to increase bread functionality: effect on physical, nutritional, sensory properties and on consumer response. International Journal of Food Science \& Technology, 53 (10), 2290-2297. doi: 10.1111/ijfs.13 820

Purlis, E. (2010). Browning development in bakery products - a review. Journal of Food Engineering, 99(3), 239-249. doi: 10.1016/j.jfoodeng.2010.03.008
Saeleaw, M., \& Schleining, G. (2010). Effect of blending cassava starch, rice, waxy rice and wheat flour on physicochemical properties of flour mixtures and mechanical and sound emission properties of cassava crackers. Journal of Food Engineering, 100(1), 12-24. doi: 10.1016/1.1foodeng.2010.03.020

Sardá, F. A. H., Lima, F. N. R., Lopes, N. T. T., Santos, A. O., Tobaruela, E. C., Katoc, E. T. M., \& Menezes, E. W. (2016). Identification of carbohydrate parameters in commercial unripe banana flour. Food Research International, 81(1), 203-209. doi: 10.1016/j.foodres.2015.11.016

Savlak, N., Türker, B., \& Yesilkanat, N. (2016). Effects of particle size distribution on some physical, chemical and functional properties of unripe banana flour. Food Chemistry, 213(1), 180-186. doi: 10.10 16/j.foodchem.2016.06.064

Serial, M. R., Blanco Canalis, M. S., Carpinella, M., Valentinuzzi, M. C., León, A. E., Ribotta, P. D., \& Acosta, R. H. (2016). Influence of the incorporation of fibers in biscuit dough on proton mobility characterized by time domain NMR. Food Chemistry, 192(1), 950-957. doi: 10.1016/j.foodchem.2015. 07.101

Sharma, S., Saxena, D. C., \& Riar, C. S. (2016). Nutritional, sensoryand in-vitro antioxidant characteristics of gluten free cookies prepared from flour blends of minor millets. Journal of Cereal Science, 72(1), 153-161. doi: 10.1016/j.jcs.2016.10.012

Someya, S., Yoshiki, Y., \& Okubo, K. (2002). Antioxidant compounds from banana (Musa Cavendish). Food Chemistry, 79(1), 351-354. doi: 10.1016/S0308-8146(02)00 186 
Sulaiman, S. F., Yusoff, N. A. M., Eldeen, I. M., Seow, E. M., Sajak, A. A., Supriatno, \& Ooi, K. L. (2011). Correlation between total phenolic and mineral contents with antioxidant activity of eight Malaysian bananas (Musa sp.). Journal of Food Composition and Analysis, 24(1), 1-10. doi: 10.1016/j.jfca.2010. 04.005

Sung, W.C., \& Chen, C.Y. (2017). Influence of cookies formulation on the formation of acrylamide. Journal of Food and Nutrition Research, 5 (6), 370-378. doi: 10.12691/ jfnr-5-6-3

Thejasri, V., Hymavathi, T. V., \& Roberts, T. P. P. (2017). Sensory, physico-chemical and nutritionalproperties of glutenfreebiscuits formulated with quinoa (Chenopodium quinoa willd.), Foxtail Millet (Setaria italica) and Hydrocolloids. International Journal of Current Microbiology and Applied Sciences, 6(8), 1710-1721. doi: 10.20546/ ijcmas.2017.608.205
Vu, H. T., Scarlett, C. J., \& Vuong, Q. V. (2018). Phenolic compounds within banana peel and their potential uses: a review. Journal of Functional Foods, 40(1), 238-248. doi: 10.1016/j.jff.2017.11.006

Witczak, M., Ziobro, R., Juszczak, L., \& Korus, J. (2016). Starch and starch derivatives in gluten-free systems- a review. Journal of Cereal Science, 67(1), 46-57. doi: 10. 1016/j.jcs.2015.07.007

Xu, J., Zhang, Y., Wang, W., \& Li, Y. (2020). Advanced properties of gluten-free cookies, cakes, and crackers: A review. Trends in food science \& technology, 103(1), 200-213. doi:10.1016/j.tifs.2020 07.017

Zhu, F. (2015). Composition, structure, physicochemical properties and modifications of cassava starch. Carbohydrate Polymers, 122(1), 456-480. doi: 10.1016/j.carbpol.2014.10.063 
